\title{
LUKASZ MONIUSZKO
}

Uniwersytet Zielonogórski

\section{O możliwości zastosowania teorii prawa Zygmunta Ziembińskiego w rozstrzyganiu problemów bioetycznych}

Słowa kluczowe: Ziembiński, bioetyka, prawo, moralność, ciąża Key words: Ziembiński, bioethics, laws, morality, pregnency

\section{SUMMARY}

On the possibility of applying the theory of Zygmunt Ziembiński's law in resolving the problems of bioethics

The article looks at attempts to use the legal and moral concepts of Zygmunt Ziembiński in bioethical considerations. Assuming that law is determined by morality, the an example of an unborn child is used to examine how these combined factors can be applied in bioethics. According to the author, the most interesting aspects are the proposals formulated by Ziembiński. In his opinion, the liberal theory of Ziembiński's law, which expands on the views of Maria Ossowska and Czeslaw Znamierowski, deserves special attention.

In summing up, the author comes to the conclusion that the concept of Ziembiński's law can find universal application in bioethics, thanks to its more than subjective practical applicability. 


\section{Wstęp}

Bioetyka to dział etyki, który dynamicznie rozwija się w miarę postępu nauk biologicznych. Łączy ona w sobie elementy wielu dyscyplin naukowych, jednak najbardziej zauważalne są wpływy filozofii, medycyny i prawa. Podkreślić należy, że ciągle trudno dobrać elementy systemu prawa dla skutecznej analizy problemów bioetycznych z powodu funkcjonowania $\mathrm{w}$ praktyce społecznej wielu rozbieżnych stanowisk prawno-moralnych, w tym nawet prób wykazywania autonomii prawa od moralności. Uznać jednak należy, że przy obecnym rozwoju nauk biologicznych dyskusja nad moralnymi aspektami współczesnej medycyny bez wypracowania stosownych norm prawnych jest jałowa i z całą pewnością nie może rodzić skutecznej metody rozwiązywania problemów, z jakimi musi mierzy się współczesny człowiek. Rozpatrywanie sporów o dopuszczalność aborcji, eutanazji czy antykoncepcji wyłącznie przez pryzmat funkcjonującej moralności jest niepełne. Z drugiej jednak strony analiza jedynie prawna tych właśnie problemów nie pozostawia miejsca na namysł moralny, gdyż już sam przepis aprobuje określone stanowisko, a za każde inne przewiduje sankcje. Najrozsądniejsze jest zatem przyjęcie założenia o możliwości skutecznej syntezy norm etyki i prawa, co uwidacznia się właśnie w bioetyce.

Racjonalną propozycję połączenia i wykazania nierozerwalnej zależności prawa i moralności wypracował poznański teoretyk prawa, socjolog i filozof Zygmunt Ziembiński. Jego koncepcja wydaje się być na tyle szczegółowa, że może z powodzeniem zostać wykorzystana w roli narzędzia rozstrzygania problemów, jakie przynosi debata bioetyczna.

W prezentowanym szkicu spróbujemy wykazać na przykładzie ciągle żywego sporu o ochronę życia poczętego, jak istotnym elementem racjonalnej dyskusji na ten temat jest współzależność prawa i moralności. W przekonaniu autora filozofia prawa Ziembińskiego nie tylko racjonalizuje taką dyskusję, ale też może ukazać w nowym świetle problemy, które w tradycyjnym dyskursie nie mogły doczekać się racjonalnego rozstrzygnięcia. 


\section{Status moralny ludzkiego płodu jako konsekwencja ocen i norm}

Ziembiński trafnie zwraca uwagę, że moralności nie sposób pojmować inaczej jak tylko jako zbioru ocen i norm faktycznie akceptowanych przez jednostkę lub grupę, lub też tylko postulowanych przez jakąś doktrynę. Rozróżnia on przy tym normy i oceny autonomiczne wyznawane przez daną osobę oraz heteronomiczne znajdujące uzasadnienie w ocenach innych podmiotów, zbiorowości lub organizacji uznawanej za autorytet moralny. $W$ tym przypadku to autorytet rozstrzyga o tym, co jest dobre, a co złe. Przykładem wyznaczania ocen heteronomicznych są wskazania przywódców religijnych, a ponadto w doktrynach religijnych życie poczęte zajmuje zawsze eksponowane miejsce i podlega szczególnej ochronie moralnej (Ziembiński 1963: s. 30).

Poznański filozof podkreślał także rolę wiedzy i doświadczenia jako czynników determinujących sposób formułowania norm moralnych. Podkreślał przy tym, że organizacje pozapaństwowe nie muszą uwzględniać takich problemów jak demografia, sytuacja ekonomiczna czy zdrowotna lub socjalna społeczeństwa (Ziembiński 1980, s. 497). I tak Jan Paweł II w jednym z przemówień wskazał, że jeżeli się rozwazy programy rzadowe czy systemy pomocy, które potencjalnie zmuszaja wspólnoty czy kraje do przyjęcia planu antykoncepcji bądź przerywania ciąży jako ceny za rozwój ekonomiczny, to trzeba powiedzieć jasno i dobitnie, że oferty te sa pogwałceniem solidarności ludzkiej rodziny, gdyż zaprzeczaja wartościom godności człowieka i ludzkiej godności (Korba: 2006: 27). Zdaniem Ziembińskiego taka krytyka jest dozwolona nie tylko moralnie lecz również prawnie, zwłaszcza jeśli dyskusji podlega życie ludzkie.

Nie sposób nie wspomnieć o ciąży powstałej w wyniku zgwałcenia. Czy można żądać od kobiety by donosita i urodziła taki płód narzucony jej przez gwałt? (Wiśniewska-Roszkowska 1991: s. 71). Równie ważnym problemem są sytuacje krytyczne, kiedy płód zagraża zdrowiu lub życiu matki. Jest to tak zwana aborcja terapeutyczna, która określa sytuacje, w której życie matki znajduje się w poważnym niebezpieczeń- 
stwie, co spowodowane jest stanem ciąży, w którym się znajduje. Chodzi tutaj o zagrożenia nie tylko natury fizycznej ale również psychicznej czy umysłowej. W takich przypadkach niektórzy sa w stanie dopuścić aborcje $z$ racji tzw. medycznych wskazań (...) ze względu na ratowanie życia i zdrowia matki (Kawecki 1996: 59). Powstaje jednak kolejna wątpliwość - gdzie jest granica wolności ludzkiej? W tym przypadku przyszłej matki. Skoro płód zagraża jej życiu, to czy nie powinny istnieć regulacje, choćby moralne, zdecydowanie nakazujące w tym przypadku usunięcia ciąży? Może należy jednak pozostawić tę sprawę sumieniu matki? Ziembiński nazywa podejmowanie krytycznych decyzji dotyczących innych istot jako pojmowanie współrodzajowe. Określają one wobec kogo istnieje jakiś obowiązek moralny, a zatem w analizowanym przypadku - kogo przyszła matka ma obowiązek chronić. Istnieją oczywiście jedynie dwie możliwości - siebie lub nienarodzone dziecko. Ziembiński w swych rozważaniach odwołuje się do pojęcia sprawiedliwości, które jednak proponuje rozumieć na kilka sposobów. Bez wątpienia płód ludzki należy darzyć życzliwością jak każdą inną istotę. Nasuwa się jednak pytanie, czy istnieją granice takiej życzliwości? Czy sprawiedliwsza dla matki będzie możliwość dokonania aborcji płodu pochodzącego ze zgwałcenia lub w sytuacji jego uszkodzenia nierokującego narodzin zdrowego potomka? Czy zawsze może uznać za sprawiedliwe bezwzględne prawo do życia? Ziembiński stwierdza, że pojmując moralność jako zbiór zasad dobrego współżycia społecznego (...) opartego na życzliwości sprawiedliwej, to znaczy takiej, która nie wyróżnia poszczególnych ludzi indywidualnie, lecz każe jednakowo traktować wszystkich, którzy maja jakieś cechy uznawane (...) za istotne (Ziembiński 1978: 65). W rozważanym przypadku za taką istotną cechę uznać należy człowieczeństwo. Analizie zatem należy poddać czy w sytuacjach krytycznych większym poziomem człowieczeństwa „wykazuje się" matka czy nienarodzone dziecko.

Kontynuując myśl poznańskiego filozofa zwrócić należy uwagę, że w większości rozważań rozróżnia się sprawiedliwość rozdzielczą i sprawiedliwość wyrównawczą. Pierwsza określa, w jaki sposób rozdzielić 
dobro lub zło. Druga zaś nakazuje świadczenie odpłaty za doznane dobro lub zło (Ziembiński 1996: 52-62). Na pierwszy rzut uznać możemy, że w rozważanej sytuacji istnieje paradoks pozwalający na pozbawienie życia płodu a następnie ukaranie matki za przedwczesne zakończenie tego życia. Kluczem do właściwej interpretacji tego paradoksu jest rozpatrzenie tej sytuacji, w jakimś kontekście społecznym. Sprawiedliwość jest bowiem wartością konstytuującą funkcjonowanie wspólnot ludzkich. Jak podkreśla Ziembiński przyjęcie takiej czy innej konkretnej formuły sprawiedliwości we współżyciu między ludźmi jest jednym $z$ podstawowych wyznaczników treści norm moralnych, a poszczególne formuły tego rodzaju maja duża doniosłość, służac jako uzasadnienie takiego czy innego układu stosunków społecznych (Ziembiński 1978: 65).

Przy rozstrzygnięciu tej sytuacji doniosłe znaczenie wydaje się mieć proponowane przez Ziembińskiego określenie dóbr pierwszych oraz dóbr instrumentalnych. Stanowią one cechy szczególne ocen moralnych danych czynów. Ocenie moralnej podlegają bowiem nie same czyny ale to, ile powodują lub mogą powodować dobra lub zła dla innych istot uznawanych za znaczące dla społeczeństwa. Dlatego też treść ocen i norm moralnych może ulegać zmianie, co jest zależne od tego, co uważa się za cenniejsze dobro (Wronkowska et al. 1974: s. 25-27). Należy odróżnić przy tym dobra, które Ziembiński nazwał pierwszymi a więc bezwzględnie cenne dla wszystkich grup społecznych, a także aparatu państwowego, czyli takich jak życie, zdrowie czy wolność od dóbr instrumentalnych służących jako środek do osiągnięcia tych pierwszych. Oczywiście spór o to, jakie dobra uważa się za pierwsze, a jakie za instrumentalne pozostaje nierozstrzygnięty. W przypadku ciąży zarówno życie matki, jak i życie płodu uznane może być za dobro pierwsze lub dobro instrumentalne, w zależności od tego, które z nich ma podlegać wyższej ochronie. Ziembiński trafnie podkreślał, że niezgoda co do wskazania dóbr pierwszych powstaje na podstawie indywidualnych światopoglądów i ma zazwyczaj charakter emocjonalny. Spór o dobra instrumentalne jest zatem najczęściej dyskusją o charakterze intelektualnym, próbą określenia czy są one wystarczającym środkiem 
do osiągnięcia dóbr pierwszych (Ziembiński 1978: 67-68). Przykładem takiej dyskusji nad rozwojem prenatalnym może być proces tworzenia ustaw, które zawsze zakładają ochronę jakiegoś dobra, nawet kosztem innego, które w danym momencie uznano za mniej cenne społecznie. Doniosłość społeczna jest kwestią sporną i zależy od podmiotu oceniającego tę wartość.

Konieczne zatem jest uwzględnienie możliwości poświęcenia pewnych dóbr dla osiągnięcia innych. Zwraca na to uwagę także Ziembiński wykorzystując przy tym analizy klasyków teorii prawa w rodzaju Petrażyckiego (Petrażycki 1959: 10-14). Podkreśla on, że wybór środków działania zmierzających do osiągnięcia dóbr zasadniczych stawia często człowieka przed koniecznością dokonania moralnego wyboru. W koncepcji tej zawarte jest pytanie: czy cel uświęca środki?, a jeśli tak, to w jakich granicach? Nie sposób kwestionować wartości życia przyszłej matki, jeśli ciąża stanowi dla niej zagrożenie. Nie sposób kwestionować również potrzeby zachowania jej zdrowia psychicznego, gdy dziecko pochodzi ze zgwałcenia, a jego urodzenie wiązać się musi z drastycznymi wspomnieniami. Wydaje się, że zdrowie i życie matki w przeświadczeniu społecznym ma znaczenie na tyle wymierne, że należy takiej kobiecie zapewnić możliwość ciąży upragnionej, niezagrażającą jej życiu i nieprzywołującej bolesnych wspomnień. Jednak z drugiej strony mamy tu do czynienia także z wartościami niemierzalnymi, np. czy można pozbawić życia odrzucając wszelkie przeszkody niewinne stworzenie dla doraźnego interesu matki, a pośrednio, także dla interesu społecznego. Nic zatem dziwnego, że zasady poświęcania pewnych dóbr na rzecz innych ciągle są przedmiotem sporów pomiędzy różnymi doktrynami moralnymi (Ziembiński 1978: 68-74).

Dla rozważań bioetycznych istotne są również uwagi Ziembińskiego stwierdzające, że szczególną odmianą sporów tego rodzaju jest dyskusja o tym czy normy moralne przybierać winny formę kazuistyczną czy ogólną. Pierwsza z nich zakładać musi, że każdy przypadek indywidualny ciąży podlegać powinien ocenie adekwatnej do istniejącej 
sytuacji, z uwzględnieniem całej złożoności poszczególnych jej elementów. Forma ogólna zatem zakładać musi wypracowanie ogólnych zasad postępowania w każdym przypadku przerywania ciąży. Jej opracowanie oparłoby się na analizie typowego przypadku, nie dopuszczające sytuacji kazuistycznych nawet w wyjątkowych sytuacjach, takich jak ciążą pochodząca ze zgwałcenia lub związana z zagrożeniem życia matki. Jak podkreśla autor „Logiki praktycznej”, pryncypializm moralny w poszczególnych przypadkach może wyrządzić więcej zła niż dobra, jakkolwiek uniwersalne zasady moralne (np. aby nie kłamać, nie zadawać cierpień, szanować godność ludzką) wyznaczają jasne reguły postępowania, co powinno uwalniać od niepotrzebnych wahań, a przez to utrwalać istniejący porządek społeczny. Również kazuistyczne formułowanie norm moralnych pozwala kierować się ocenami płynącymi z konkretnych przypadków, ale również kryje niebezpieczeństwo łatwego usprawiedliwiania wątpliwych moralnie decyzji wynikłych z nietrafnej oceny zdarzeń. Przykładem tutaj może być stan psychiczny przyszłej matki. Wprawdzie przesłanka zagrożenia dla zdrowia może zostać teoretycznie spełniona, i to z dużym prawdopodobieństwem, ale łatwo można podmiot oceniający ten stan wprowadzić w błąd. Chęć pozbycia się niechcianej ciąży może spowodować, że ciężarna stwierdzi nieprawdę, np. iż padała ofiarą zgwałcenia (Ziembiński 1978: 69).

W aspekcie moralnym nie sposób wypracować skuteczne rozwiązania przedstawionych problemów. Prezentowane stanowiska etyczne mogą jedynie promować pożądane zachowania. Niejednokrotnie samo potępienie moralne nie wywoła stosownej refleksji u matki, która postanowiła przerwać ciążę. W związku z istniejącymi barierami mentalnymi istnieje potrzeba budowania systemów prawnych opartych na fundamentach moralności i obyczajowości, które regulują zakres potencjalnej wolności jednostek za pomocą legislacyjnych nakazów i zakazów. 


\section{Prawna ochrona życia płodowego - uszczegółowienie zasad moralnych przez normy prawne}

W filozofii prawa przeważa opinia, że prawo jest wytworem moralności. Z norm moralnych tworzy się normy prawne, które są uszczegółowieniem zasad moralnych (Ziembiński 1963: 129). Ziembiński zaś analizując kwestie śmierci i umierania sugerował, że opieranie się na przepisach prawnych jest niezbędnym elementem dla obiektywnej analizy problemu i orzekania w sposób niezależny od stanowisk zajmowanych przez zainteresowane osoby i instytucje. Podkreślał również, że zapisy w kodeksie karnym - w rodzaju „kto zabija człowieka” - cechuje podtekst emocjonalny. Nie pomaga to zapewne w wyzbyciu się subiektywizmu bo nie sposób uniknąć takiej tendencyjności, gdy analizie poddaje się taką wartość jak życie ludzkie. Ziembiński proponuje rozpocząć dyskusję wokół śmierci od próby określenia tego, czym jest człowiek i życie. Jest to niezbędne dla określenia czy w danym przypadku mamy do czynienia z zabijaniem, czy tylko pozorami takiego czynu, albo może z jakimś przyczynianiem się do śmierci, które nie jest zabijaniem. (Ziembiński 1975: 107-108). Zadaniem prawa jest chronienie życia, lecz boryka się ono przy tym $z$ analogicznymi problemami jak medycyna przy określeniu kryteriów życia, traktując je jako zjawisko biologiczne, psychiczne względnie socjologiczne.

Prawo stanowi wartość instrumentalną, a zatem służyć ma przede wszystkim ochronie wartości samoistnych, wyinterpretowanych intuicyjnie w epoce obowiązywania jeszcze prawa natury, jako wyrazu pewnej umowy społecznej. Ziembiński podkreślał, że jest to problem bardzo istotny, gdyż w zależności od tego, o jakie samoistne wartości chodzi, odmienny będzie sposób argumentowania na rzecz akceptacji prawa. Dla jednego człowieka naczelną wartością może być wolność brzemiennej, częścią organizmu której jest płód, a zatem przyzwala na usunięcie go tak jak np. migdałów. Inni uznają, że życie, nawet w fazie prenatalnej, jest wartością wyższą od wolności matki i już samo jego istnienie musi ograniczyć jej wolność przy decydowaniu o jego płodu 
(Ziembiński 1990: 97). Skoro najbardziej przewidywalnym działaniem przeciwko rozwojowi prenatalnemu jest aborcja to naturalnym jest, że większość przepisów prawa skupia się właśnie na niej. Czy jednak tylko poprzez spędzenie płodu można dopuścić do nienarodzenia dziecka? Wiadomo przecież, że nie, ale w tym przypadku tok rozumowania prawników wymaga odrębnej analizy.

Już Arystoteles wyróżnił trafnie w tworzeniu prawa dwie przeciwstawne orientacje (Olszewski 1982: 25), wśród których wyróżnił orientację nastawioną na interesy obywateli a przeciwstawił jej orientację nakierowaną na interesy rządzących. Choć z reguły druga z tych orientacji uważana jest za wypaczenie, to $\mathrm{w}$ analizach $\mathrm{z}$ zakresu etycznych podstaw prawa obie znajdują zastosowanie. Posługując się się przykładem ochrony życia poczętego uznać należy, że umieszczenie zapisów o tej ochronie jest interesem zarówno społecznym, jak i politycznym. Interes społeczny zauważalny jest od razu, interes polityczny zauważalny jest często po latach, choćby w postaci większej liczby pracujących, a więc napędzających gospodarkę (Wronkowska, Ziembiński 2001: 227).

Punktem wyjścia rozważań prawnych opartych na konkretnych przepisach musi być Konstytucja. Ziembiński uważa za niezbędne wyjście od tego aktu prawnego we wszystkich dyskusjach dotyczących zagadnień prawnych. Podkreślał, że Konstytucja RP odnosi się w zasadzie do ogólnego określenia wszelkich wartości i dóbr. Nadaje zatem wartościom moralnym wymiar prawny. Zatem podmiotami konstytuującymi te wartości, a więc biorącymi udział w nadawaniu kształtu najwyższego aktu prawa, są wszyscy członkowie społeczeństwa. Akt ten bowiem jest wyrażeniem oceny uniwersalnych zachowań, które następnie są konkretyzowane w poszczególnych ustawach (Ziembiński 1993: 21). Koncepcja ta mimo upływu czasu zachowuje uniwersalne znaczenie. Za „łącznik” między moralnością a prawem uznała konstytucję również M. Ossowska, dla której odróżnienie ocen moralnych od ocen dokonywanych $w$ innym aspekcie wymagałoby obszernych rozważań metaetycznych, które prowadziłyby do wniosku, że w dysputach etycznych spotykamy się nie tylko z różnorodnościa (...) ocen moralnych (...) lecz 
również z różnorodnymi koncepcjami, co do tego, na czym normy moralne polegaja. (Prawo nie wprowadza samych norm, a tylko definiuje ich istotę). (Ossowska 1947: 296).

W intencji Zgromadzenia Ogólnego zatwierdzającego tekst ustawy zasadniczej zapisano: Konstytucja jest szczególnym aktem prawnym, uroczyście określanym jako ustawa zasadnicza, która stanowi najwyższe prawo Rzeczpospolitej Polskiej. Jest ona fundamentem państwa i systemu prawnego. (A: wprowadzenie: V). Zatem wszystkie pochodne ustawy i rozporządzenia muszą być zgodne z Konstytucją. Naczelna ustawa określa także warunki ochrony życia ludzkiego. Podobnie jak w wielu konstytucjach państw demokratycznych, ustawa zasadnicza Rzeczpospolitej Polskiej określa zakres podstawowych praw i wolności człowieka, stawiając życie ludzkie najwyżej w hierarchii wartości. Wszelkie wartości mają być kierowane na zaspokojenie podstawowych praw jednostki, w tym przede wszystkim prawa do życia. Władza nie może bez uprawnienia konstytucyjnego ingerować w życie jednostki. Jednostka ma natomiast prawo wymagać od państwa określonych zachowań na swoją korzyść. Tak więc państwo istnieje dla człowieka, a nie odwrotnie. Zwrócić należy uwagę, że w Konstytucji używane są dwa terminy dla określenia osoby - pierwsze z nich to „obywatel" (Zob. A:art. 1, art. 61, art. 67, art. 68 u. 2, art. 70 u. 3), drugie to „człowiek” (A: art. 37 u.1, art. 39, art. 51 u. 1, 3-4). Pierwsze z nich charakteryzuje przedstawiciela państwa polskiego i nie pozostawia w tym względzie żadnych wątpliwości, gdyż art. 34 ust. 1 stwierdza: Obywatelstwo polskie nabywa się przez urodzenie (A: art.3 u. 1). Zatem warunkiem osiągnięcia statusu obywatela jest konieczność życia poza łonem matki. Wątpliwości może budzić to, co rozumie się pod pojęciem człowieka. Wśród komentatorów Konstytucji istnieje rozbieżność, co do interpretacji terminu „człowiek”. Jedynym wspólnym mianownikiem tych dyskusji jest uznanie go za synonim ,istoty ludzkiej”. Zwolennicy traktowania nienarodzonego dziecka jako wartości chronionej przez państwo powołują się na treść art. 30, który mówi m.in., że przyrodzona i niezbywalna godność człowieka stanowi źró- 
dło wolności i praw człowieka i obywatela. Jest ona nienaruszalna, a jej poszanowanie i ochrona jest obowiązkiem władz publicznych (A: art. 30). Lecz paradoksalnie przeciwnicy uznawania nienarodzonego człowieczeństwa również posiłkują się tym zapisem. W przepisie tym jest mowa odrębnie o człowieku i obywatelu. Zatem jakby inne obowiązki prawne mógł posiadać człowiek, a inne obywatel.

Wielu konstytucjonalistów nawet uważa, że prawa i wolności człowieka znajdują aksjologiczne uzasadnienie w samym człowieczeństwie. Godność ta jest niezbywalna, a więc nie można się jej nawet wyrzec. Praw i wolności nie uzasadnia się innymi przepisami, gdyż traktuje się je jako obszar oczywisty. Tak więc poszanowanie godności człowieka nie jest jedynie obowiązkiem państwa, ale również jednostek. Uznać należy, że ustawodawca wprowadzając do Konstytucji zapis o godności ludzkiej opowiedział po stronie doktryn naturalistycznych (lub co najmniej nie-pozytywistycznych) (Ziembiński 1980: 244-260), które zakładają, że porządek aksjologiczny jest obiektywny, niezależny do opcji politycznych, ideowych czy ekonomicznych. Toczony w tej sprawie dyskurs nadal jednak pozostaje nierozstrzygnięty ponieważ niektórzy uznają człowieczeństwo od chwili poczęcia lub przekroczenia pewnego okresu ciąży, podczas gdy inne stanowiska uznają człowieczeństwo dopiero od chwili narodzin (Winczorek 2008: 79-81).

Równie szeroko dyskutowany w środowiskach prawniczych i filozoficznych jest art. 38 Konstytucji. Rzeczpospolita Polska zapewnia każdemu człowiekowi prawna ochronę życia (A: art. 38). Dla konstytucjonalistów oznacza to na ogół, że życie jest najważniejszym dobrem człowieka. Ochrona państwowa nie może oczywiście gwarantować samego życia, ale przez odpowiednie uregulowania normatywne zapewnia prawną jego ochronę, która przysługuje każdemu człowiekowi, bez względu na właściwości indywidualne. Ochrona taka ma charakter bezpośredni, czyli wynika wprost z samej Konstytucji, bez konieczności interpretacji i tworzenia przepisów szczegółowych. Ustawowo powinno się jednak uwzględniać ten nakaz poprzez uregulowania bardziej szczegółowe służące minimalizacji zagrożeń dla życia ludzkiego. Prawnej ochronie 
życia służą między innymi konkretne przepisy prawa cywilnego, karnego czy ochrony środowiska (Winczorek 1998: 96).

Zapis art. 38 często interpretowany bywa jako uzasadniający istnienie zakazu lub co najmniej ograniczeń prawnych dotyczących procedury przerywania ciąży. Jednak i taka interpretacja jest nieco dyskusyjna. Wszystko bowiem zależy od tego czy płód traktuje się jako człowieka, a życie płodowe jako życie ludzkie. Zakładając odpowiedź pozytywną zmierzyć się należy z kolejnym problemem: który moment uznać za powstanie życia, czy poczętą zygotę, embrion, czy może dopiero zarodek? Większość prawników wskazuje, że opowiedzenie się za stanowiskiem pozytywnym logicznie nakazuje ochronę życia od chwili poczęcia albo chronimy albo nie. W przypadku stanowiska negatywnego sprawa wydaje się być prosta: człowiekiem jest istota narodzona. (Winczorek 1998: 96). Również Zygmunt Ziembiński na przykładzie wartości życia uzasadniał nakazy i zakazy konstytucyjne. Treść art. 38 jest zatem doskonałym przykładem konieczności istnienia obwarowań prawnych ludzkiej wolności oraz procedury przejścia od ocen do norm, co wyraża się w uniwersalnej zasadzie nakazu czynienia tego, co dobre oraz powstrzymywania siebie i innych od czynienia tego, co złe (Ziembiński 1993: 38). Niezależnie jednak od zajmowanego stanowiska paradoksalnie stwierdzić należy, że zapis ten na tle uregulowań konstytucyjnych gwarantować może ustawową ochronę płodu ludzkiego, ale dopuszcza może również przerywanie ciąży w pewnych jasno określonych przypadkach takich jak: ciężkie uszkodzenie płodu, gdy ciąża jest efektem przestępstwa lub zagraża ona życiu lub zdrowiu kobiety. Wniosek z tego płynący jest zatem taki, że choć życie jest dobrem najwyższym nie może być bezwzględnie chronione. Jednocześnie toczy się dyskusja czy należy doprecyzować ten przepis rozszerzając ten przepis o formułę „od poczęcia do naturalnej śmierci”. Argumentację na rzecz tych zmian przewidział Ziembiński już na trzydzieści lat przed ich pojawieniem się (Ziembiński 1964: 241). Uwzględnienie jego analiz już wówczas uchroniłoby przed sporami o konstytucyjne stwierdzenie „każdy człowiek”, które nie budziłoby wątpliwości zwłaszcza co do tego, o który etap roz- 
woju chodzi (Winczorek 2008: 96-97). Należy przy tym zwrócić uwagę, że skoro Konstytucja Rzeczpospolitej Polskiej jest aktem nadrzędnym, to wszystkie przepisy prawne w Polsce są jej podporządkowane i muszą być z nią zgodne (Ziembiński 1972: 190).

\section{Paradoks prawnych śmierci „przed urodzeniem”}

Przykładem tego podporządkowania jest obecnie obowiązujący kodeks karny, który w rozdziale XIX opisuje przestępstwa przeciw życiu i zdrowiu, określa chronione dobra oraz kary za zamachy na nie. Przedmiotem ochrony jest tutaj wprawdzie życie ludzkie lecz ze specjalistycznych komentarzy wynika, że jest to życie od momentu narodzin do śmierci. Jak wskazał SN, petna prawna ochrona zdrowia i życia przysługuje (również) dziecku nienarodzonemu lecz dopiero od momentu rozpoczęcia porodu, w wypadku operacyjnego zabiegu cięcia cesarskiego kończącego ciąże na żądanie kobiety ciężarnej, od podjęcia pierwszej czynności medycznej bezpośrednio zmierzajacej do przeprowadzenia takiego zabiegu, w przypadku zaś konieczności medycznej przeprowadzenia zabiegu cięcia cesarskiego lub innego alternatywnego zakończenia ciąży, do zaistnienia medycznych przesłanek takiej konieczności (Mozgawa 2012: 343). Jak się zatem okazuje zabójstwa można dokonać także na dziecku nienarodzonym. Uznać zatem należy, że w pewnych przypadkach decyzja lekarza jest momentem kluczowym, jeśli chodzi o status dziecka gotowego do przyjścia na świat. Tak więc, czego będziemy dowodzić poniżej, bezprawny atak na kobietę ciężarną przed rozpoczęciem porodu nie jest atakiem na nienarodzone dziecko, nawet jeśli jest ono w stanie przeżyć poza jej łonem. Jest to jedynie działanie skierowane przeciw niej. Ten niuans prawny wskazywał również Ziembiński uznając, że można spowodować śmierci bez dokonania zabójstwa, zatem można także zabić bez powodowania śmierci w rozumieniu medycznym i prawnym. Płód bowiem może zostać usunięty z organizmu matki zanim wykształci się w nim mózg, a przecież najpopularniejszą obecnie definicją śmierci jest stwierdzenie, że w pniu mózgu doszło do 
nieodwracalnych zmian (Por. Ziembiński 1975: 109). Zapewne dlatego wśród analityków prawa istnieje wiele nieporozumień, co do określenia znamion zabójstwa. Wielu z nich uważa, że uśmiercanie narodzonych dzieci przez matki należy rozpatrywać jako osobny problem, nie mieszczący się w granicach artykułu 148 k.k. Problem ten rozwiązuje pośrednio artykuł 149 k.k., który opisuje: Matka, która zabija dziecko w czasie porodu lub pod wplywem jego przebiegu, podlega karze pozbawienia wolności od 3 miesięcy do lat 5 (B: art. 149). Skoro ustawodawca zakłada możliwość zabicia dziecka w czasie porodu, to bierze pod uwagę, że nie musi ono być narodzone, lecz może znajdować się może jeszcze w łonie matki, a więc w prenatalnej fazie życia. Skoro zatem w takim przypadku jest to zabójstwo nienarodzonego jeszcze człowieka, to wykluczone jest spędzenie płodu czyli aborcja, na którą w kodeksie zamieszczono osoby przepis. Przepis ten będzie miał zastosowanie jedynie w dwóch przypadkach: jeśli do uśmiercenia płodu (w trakcie porodu) lub dziecka (jeśli się już narodziło) doszło „w okresie porodu” lub „pod wpływem jego przebiegu". Trafnie zatem wskazuje się w tym przypadku, że przedmiotem ochrony tego zapisu jest - podobnie jak w przypadku zabójstwa osoby dorosłej - życie (Mozgawa 2012: 351-352). Zauważyć należy, że koncepcja to również zakłada niekonieczność narodzin dla zaistnienia zabicia człowieka. Nie jest to aborcja, ale zabójstwo, pomimo że dziecka jeszcze fizycznie może nie być na świecie (C: 1981).

Aborcja jako niedopuszczenie do narodzenia dziecka zajmuje w przepisach karnych równie ważne miejsce. Oczywistym wydaje się, że skoro ustawodawca powyższe zachowania uznał za uśmiercenie, to wpisując do kodeksu aborcję miał na myśli, coś innego niż zabicie człowieka. Przepisy kodeksu karnego zatem mają chronić życie od samego poczęcia co bezpośrednio wskazuje art. 152 k.k. Zapis ten nierozerwalnie związany jest ze stanem ciąży, za który najczęściej uważa się stan organizmu kobiety od momentu zapłodnienia do porodu. Należy podkreślić najczęściej spotykany w literaturze medycznej pogląd, że zapłodniona komórka „hodowana” w warunkach laboratoryjnych nie jest ciążą, a zatem jej likwidacja nie jest przerwaniem ciąży, a więc i rozwija- 
jącego się życia. Warto w tym kontekście zwrócić również baczniejszą uwagę na paragraf 3 tego artykułu, który mówi o aborcji płodu gdy jego rozwój pozwala na przeżycie poza organizmem matki. Znamię takiego przeżycia nie jest jednoznacznie określone. Zdolność tę określić należy in concreto i założyć, że wraz z rozwojem medycyny granica możliwości przeżycia płodu będzie coraz bliższa czasu poczęcia (Bojarski 2012: 378).

\section{Konkluzja}

Koncepcja Ziembińskiego przedstawiająca istotę prawa dokonywaną przez pryzmat moralności wypracowana została niemal pół wieku temu. Życiu, jako wartości i jego wpływowi na społeczeństwo poznański filozof nadał niespotykane dotąd znaczenie, traktując je jako wprawdzie indywidualny atrybut, ale stanowiący zarazem także dobro ogółu. Odwołując się do moralnych obszarów prawa wskazał, że rozpatrywanie istoty życia nie jest możliwe bez wyjścia od zasad moralnych, ale zarazem nie jest też możliwa ocena moralna bez usytuowania tego problemu w ramach prawa. Jedynie takie podejście może prowadzić do rozwiązania spornych problemów dziś szczególnie chętnie podejmowanych przez bioetykę, a nawet psychologię społeczną i socjologię.

Dla przykładu stanowisko zajmowane przez chrześcijaństwo w sprawie życia poczętego eksponuje dwa aspekty. Odrębnym dyskusjom podlega aborcja, a osobno rozważany jest problem sztucznie powstałego embrionu ludzkiego. Za aborcję bioetyka chrześcijańska uznaje spędzenie płodu ludzkiego. Płodem ludzkim nazywa zaś istotę w fazie prenatalnej po ósmym tygodniu ciąży. Embrionem jest natomiast ludzki zarodek przed tym okresem. Jak podkreśla w kilku encyklikach Jan Paweł II, że choć problem istoty poczętej pojawia się w dyskusjach o aborcji to nabrał nowego znaczenia w kontekście dostępności embrionu ludzkiego w warunkach pozaustrojowych. Wszak jedynie jeden embrion sztucznie wyhodowany jest wykorzystywana do zapłodnienia in vitro. Pozostałe stają się przedmiotem eksperymentów lub są niszczone. Embrion ludzki jest w prawdzie w znacznym stopniu uzależ- 
niony od otoczenia, jednak od chwili inicjacji jego rozwoju nie zostaje z zewnątrz dodana żadna nowa jakość. Dlatego nie sposób odmówić embrionowi statusu człowieczeństwa, choć pozbawienie go możliwości rozwoju odbywa się inaczej niż tradycyjnie rozumiana aborcja (Korba 2006: 11-21, 34-41). Jest to więc problem nie tylko moralny lecz również a może przede wszystkim antropologiczny. Możliwość zajmowania rozbieżnych stanowisk przez jeden autorytet moralny niezależnie od Ziembińskiego przewidywała również Maria Ossowska wskazując, że taki rozdźwięk może jednakże prowadzić tego samego celu czyli, jak np. w rozważanym przypadku, skutecznej ochrony życia poczętego (Ossowska 1947: 345-347).

Zwróćmy uwagę, że aborcję Kościół uznaje zamierzone działanie majace na celu sztuczne przerwanie procesu płodowego rozwoju człowieka (Korba 2006: s. 11). Etyka chrześcijańska nie zakłada ponadto żadnych granic życia płodowego. Ziembiński uważał, że jest to zabieg dozwolony z uwagi na brak obwarowań formalnych organizacji wyznaniowych, którym podlegać musi państwo dla utrzymania właściwego stanu struktury społecznej.

Istotę życia Ziembiński zdaje się traktować jako problem stricte ponad normatywny, który dopiero jednostkowe sądy o rzeczywistości poprzez wyrażenie oceny sprowadzają na grunt etyki normatywnej. Ten poziom dopiero wyłania problemy szczegółowe, z których jednym jest spór o status życia poczętego (Por. Ziembiński 1994: 19-36). W tym kontekście Konstytucja RP jest meta-przepisem osadzonym na fundamencie moralnych oczekiwań społecznych, który określa zasady ogólnej ochrony życia, które ściślej precyzowane są w ustawach podrzędnych, w tym m.in. w prawie karnym (Por. Ziembiński 1993: 7). Koncepcje Ziembińskiego stanowić mogą wzór do rozpatrywania wszystkich zagadnień bioetycznych. Przemawia za tym szczególnie fakt, że większość $\mathrm{z}$ tych problemów ujęta jest w aktach prawnych, a zatem ich obiektywizacja musi mieć oparcie nie tylko w etyce, ale również w teorii prawa pozytywnego. 


\section{Bibliografia}

\section{Literatura:}

Bojarski T. (red.), 2012, Kodeks karny. Komentarz, Wyd. Lexis Nexis, Warszawa. Kawecki W., 1996, Dlaczego kościót broni życia?, Wyd. „Bratni Zew”, Kraków.

Korba A. (red.), 2006, Nauczanie moralne Jana Pawła II. Bioetyka, Wyd. Polwen, Radom. Mozgawa M.(red.), 2012, Kodeks karny. Komentarz, Wyd. Lex, Warszawa.

Olszewski H., 1982, Historia doktryn politycznych i prawnych, Wyd. Ars Boni et Aequi, Warszawa.

Ossowska M., 1947, Podstawy nauki o moralności, Wyd. Czytelnik, Warszawa.

Petrażycki L., 1959, Wstęp do nauki prawa i moralności, Wyd. PWN, Warszawa.

Winczorek P., 2008, Komentarz do Konstytucji Rzeczpospolitej Polskiej z dnia 2 kwietnia 1997 roku, Wyd. Liber, Warszawa.

Wiśniewska-Roszkowska K., 1991, Oto jestem-dlaczego chcesz mnie zabić?, w: Krenczkowski H., (red.), „W obronie życia poczętego”, Wyd. Diecezjalne Pelplin, Pelplin, 89-103.

Wronkowska S., Zieliński M., Ziembiński Z., 1974, Zasady prawa. Zagadnienia podstawowe, Wyd. Prawnicze, Warszawa.

Wronkowska S., Ziembiński Z., 2001, Zarys teorii prawa, Wyd. Art Boni et Aequi, Poznań.

Ziembiński Z., 1962, Normy moralne a normy prawne. Zarys problematyki, Wyd. Prace Wydziału Prawa UAM, Vol. 6.

Ziembiński Z.,1964, O wynikaniu norm z norm. Rozprawy logiczne, Księga pamiątkowa ku czci K. Ajdukiewicza, Wyd. PWN, Warszawa, 241-245.

Ziembiński Z., 1972, Analiza pojęcia czynu, Wyd. Wiedza Powszechna, Warszawa.

Ziembiński Z., 1975, Prawne i moralne problemy śmierci i umierania, Etyka, Vol. 14, 17-29.

Ziembiński Z., 1978, Teoria prawa, Wyd. PWN, Warszawa.

Ziembiński Z., 1980, Problemy podstawowe prawoznawstwa, Wyd. PWN, Warszawa.

Ziembiński Z., 1990, Wstęp do aksjologii dla prawników, Wyd. Prawnicze, Warszawa.

Ziembiński Z., 1992, O pojmowaniu sprawiedliwości, Wyd. Daimonion, Lublin.

Ziembiński Z., 1993, Wartości konstytucyjne, Wyd. Sejmowe, Warszawa.

Ziembiński Z., 1994, Zarys zagadnień etyki, Wyd. Edytor, Poznań.

Ziembiński Z., 1996, Sprawiedliwość społeczna jako pojęcie prawne, Wyd. Sejmowe, Warszawa.

\footnotetext{
Akty prawne:

A: Konstytucja Rzeczpospolitej Polskiej z dnia 2 kwietnia 1997 roku. (Dz. U. 1997.78.483 z dnia 16 lipca 1997 r. z późn. zm.).

B: Ustawa z dnia 6 czerwca 1997 r. kodeks karny. (Dz. U. 1997.88.553 z dnia 6 czerwca 1996 r. z późn. zm.).

C: Wyrok Sądu Najwyższego. Syn. akt: IV KR 32/81.
} 